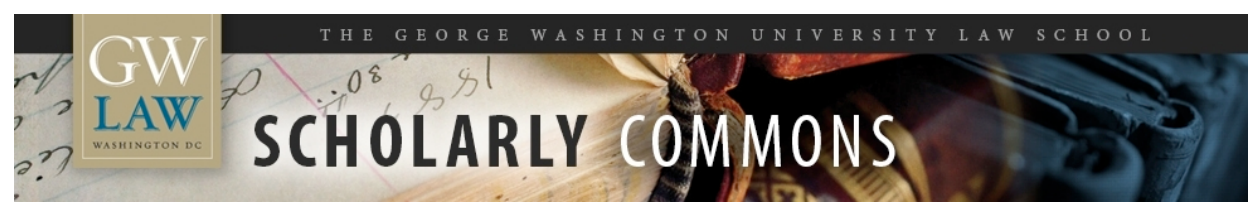

\title{
The National Labor Relations Act at 75: In Need of a Heart Transplant
}

Charles B. Craver

George Washington University Law School, ccraver@law.gwu.edu

Follow this and additional works at: https://scholarship.law.gwu.edu/faculty_publications

Part of the Law Commons

\section{Recommended Citation}

Craver, Charles B., "The National Labor Relations Act at 75: In Need of a Heart Transplant" (2010). GW Law Faculty Publications \& Other Works. 465.

https://scholarship.law.gwu.edu/faculty_publications/465

This Article is brought to you for free and open access by the Faculty Scholarship at Scholarly Commons. It has been accepted for inclusion in GW Law Faculty Publications \& Other Works by an authorized administrator of Scholarly Commons. For more information, please contact spagel@law.gwu.edu. 


\title{
THE NATIONAL LABOR RELATIONS ACT AT 75: IN NEED OF A HEART TRANSPLANT ${ }^{1}$
}

\author{
By Charles B. Craver ${ }^{2}$
}

\section{INTRODUCTION}

When the National Labor Relations Act (NLRA) ${ }^{3}$ was enacted in 1935, 13.2 percent of nonagricultural labor force participants were members of labor organizations. ${ }^{4}$ Most of these individuals were skilled craft persons who were members of craft unions affiliated with the American Federation of Labor (AFL). ${ }^{5}$ Congress stated in Section 1 that "[t]he denial by employers of the right of employees to organize and the refusal by employers to accept the procedure of collective bargaining lead to strikes and other forms of industrial strife or unrest ..." Congress also noted "[t]he inequality of bargaining power between employees who do not possess full freedom of association ... and employers who are organized in the corporate [form] ..."7 When the Supreme Court sustained the constitutionality of the NLRA, it recognized that "a single employee was helpless in dealing with an employer; that he was dependent ordinarily on his daily wage

\footnotetext{
${ }^{1}$ Copyright 2010 by Charles B. Craver

2 Freda H. Alverson Professor of Law, George Washington University Law School. J.D., 1971, University of Michigan; M. Indus. \& Labor Rels., 1968, Cornell University School of Labor \& Industrial Relations; B.S., 1967, Cornell University.

349 Stat. 449 (1935), 29 U.S.C. $§ \S 151$ et seq. (2000).

4 See MICHAEL GOLDFIELD, THE DECLINE OF ORGANIZED LABOR IN THE UNITED STATES 10 tbl. 1 (1987).

5 Id.

629 U.S.C. $\S 151(2000)$.

7 Id.
} 
for the maintenance of himself and family; that if the employer refused to pay him the wages that he thought fair, he was nevertheless unable to leave the employ and resist arbitrary and unfair treatment; [and] that union was essential to give laborers opportunity to deal on an equality with their employer." 8

By 1935, the United States had been transformed from an agrarian to an industrial economy, as large manufacturing firms had been established to produce automobiles, steel, glass, clothing, electrical equipment, and similar commodities. The highly specialized craft unions associated with the AFL were finding it difficult to organize manufacturing employees who possessed various skill levels. At the 1934 and 1935 AFL conventions, William Green and John L. Lewis sought to create AFL industrial unions, but these efforts were defeated. ${ }^{9}$ Following the 1935 convention, leaders from the United Mine Workers, the International Typographical Workers, the Amalgamated Clothing Workers, the International Ladies Garment Workers, the United Textile Workers, the Oil Field, Gas Well, and Refining Workers, the United Hatters, Cap, and Millinery Workers, and the Mine, Mill, and Smelter Workers met in Washington, D.C. to create the Committee for Industrial Organization. ${ }^{10}$

The Committee for Industrial Organization established different organizing committees pertaining to the steel, textile, automobile, rubber, chemical, shipping, and electronics industries. AFL President Green expressed his dissatisfaction with these

\footnotetext{
8 NLRB v. Jones \& Laughlin Steel Corp., 301 U.S. 1, 33 (1937).

9 See PHILIP TAFT, ORGANIZED LABOR IN AMERICAN HISTORY 468-69 (1964).

10 See PHILIP TAFT, THE A.F. OF L. FROM THE DEATH OF GOMPERS TO THE MERGER 471-72 (1959).
} 
splinter AFL entities, and trade union officials severely criticized the Committee for Industrial Organization for its "dual union" efforts at the $1937 \mathrm{AFL}$ convention. ${ }^{11}$ In 1938, the labor organizations participating in the Committee for Industrial Organization withdrew from the AFL and formed the Congress of Industrial Organizations (CIO). ${ }^{12}$ During the following two decades, AFL craft unions and CIO industrial unions competed with each other to organize workers employed in the emerging mass production industries. By the mid-1950s, 34.7 percent of American workers were members of labor organizations. ${ }^{13}$

Corporate leaders were becoming increasingly concerned about the diminishing profits caused by higher labor costs associated with labor organizations and the collective bargaining process. ${ }^{14}$ They sought new legislation that would curtail the rights of unions and their members. In 1947, they induced Congress to enact the Labor Management Relations Act (LMRA) ${ }^{15}$ amendments to the NLRA. These amendments created union unfair labor practices and limited secondary activity by labor organizations engaged in bargaining disputes. They also outlawed the closed shop which had allowed unions to

${ }^{11}$ See id. at 472-480.

${ }^{12}$ See id. at 528-29.

${ }^{13}$ See GOLDFIELD, supra note 4, at 10 tbl. 1.

${ }^{14}$ See Craig A. Olson \& Brian E. Becker, The Effects of the NLRA on Stockholder Wealth in the 1930s, 44 INDUS. \& LAB. REL. REV. 116, 123 (1990).

${ }^{15}$ Pub. L. No. 80-101, 61 Stat. 136 (1947). 
negotiate agreements requiring employers to hire only persons who were already union members. ${ }^{16}$

Business groups induced Congress to further narrow worker and union rights in the 1959 Labor Management Reporting and Disclosure Act (LMRDA) ${ }^{17}$ amendments to the NLRA. These legislative changes expanded the scope of prohibited secondary activities and outlawed many forms of organizational and recognitional picketing. ${ }^{18}$ Other LMRDA provisions regulated internal union affairs, imposed fiduciary obligations on labor organizations, and required unions to file annual financial reports with the Secretary of Labor. ${ }^{19}$

Despite the organizing achievements of CIO industrial unions and the continued vitality of AFL craft unions, labor officials did not like the open competition between AFL and CIO entities. By late 1955, the merger of AFL and CIO unions was achieved. ${ }^{20}$ Although the reunited AFL-CIO decided not to form a separate labor party, the labor movement exerted substantial political influence. ${ }^{21}$ Political action committees contributed significant financial support to individuals supportive of worker rights, and

\footnotetext{
${ }^{16}$ See THEODORE J. ST. ANTOINE, CHARLES B. CRAVER \& MARION G. CRAIN, LABOR RELATIONS LAW: CASES AND MATERIALS $112\left(11^{\text {th }}\right.$ ed. 2005). New employees could not be required to become union members until after thirty days of employment. See 29 U.S.C. § 158(a)(3) (2000).

17 Pub. L. No. 86-257, 73 Stat. 519 (1959).

${ }^{18}$ See 29 U.S.C. $\$ \S 158(b)(4) \&(b)(7)(2000)$.

19 See 29 U.S.C. $\S 431$ (2000).

20 See TAFT, supra note 9, at 660-61.

21 See id. at 609-617.
} 
AFL-CIO affiliates lobbied in favor of legislation designed to advance employee rights. Some of the beneficial enactments that enjoyed labor support include the Equal Pay Act of $1963,{ }^{22}$ prohibiting compensation differentials between men and women performing equal work; Title VII of the Civil Rights Act of $1964,{ }^{23}$ proscribing employment discrimination based upon race, color, religion, sex, or national origin; the Age Discrimination in Employment Act of $1967,{ }^{24}$ outlawing employment discrimination against individuals forty and older; the Occupational Safety and Health Act of $1970,{ }^{25}$ protecting the employment environments of workers; the Employment Retirement and Income Security Act of $1974,{ }^{26}$ protecting the economic soundness of employee pension and welfare benefits; and the Americans with Disabilities Act, ${ }^{27}$ enhancing the employment rights of persons with significant disabilities. Labor organizations also lobbied for greater employee rights under worker and unemployment compensation statutes, and many other laws furthering worker interests.

Employer opposition to labor organizations expanded greatly during the inflationary years of the 1970s, as cost-of-living adjustment clauses in bargaining agreements required firms to increase wages to match increases in the consumer price index. Companies began to look for ways to reduce labor costs. Some transferred

22 Pub. L. No. 88-38, § 102, 77 Stat. 56-57 (1963).

23 Pub. L. No. 88-352, $\S \S 701-703$, 78 Stat. 241, 253-58 (1964).

24 Pub. L. No. 90-202, § 2, 81 Stat. 602 (1967).

25 Pub. L. No. 91-596, § 2, 84 Stat. 1590 (1970).

26 Pub. L. No. 93-406, § 2, 88 Stat. 832, 833 (1974).

27 Pub. L. No. 101-336, 104 Stat. 327 (1990). 
production to lower wage areas within the U.S., some relocated operations to lower wage countries like Mexico and China, and others demanded concession bargaining that forced labor organizations to accept reduced wages and benefits.

Unionized workers were not only being challenged by these developments, but also by significant demographic, technological, industrial, and international changes. Although union membership increased from 17,000,000 to 22,000,000 from the mid1950s through 1980, the percentage of nonagricultural labor force participants in unions declined from 35 to 23 percent due to the fact that labor organization growth did not keep pace with overall labor force growth. ${ }^{28}$ Since 1980 , the strength of unions has declined both in absolute terms and as a percentage of the nonagricultural labor force. By 1990, there were only $16,740,000$ union members in the U.S., comprising 16.1 percent of labor force participants. ${ }^{29}$ By the end of 2009, there were 15,327,000 union members, constituting a mere 12.3 percent of labor force participants. ${ }^{30}$ This figure masks the actual decline in private sector membership, because it includes the 37.4 percent of government employees who are union members. When only private sector workers are considered, the number of union members declines to 7,431,000 representing 7.2 percent of employed persons. $^{31}$

28 See GOLDFIELD, supra note 4 , at 10-11 tbls. 1 \& 2.

29 See Union Membership Stays on Downward Trend, Falling to 16.1 Percent of Employment, 26 DAILY LABOR REPORT (B.N.A.), Feb. 7, 1991, at B-8.

30 See Unions Lost 771,000 Members in 2009,As Recession Eliminated Jobs, DAILY LABOR REPORT (B.N.A.), Jan. 25, 2010, at AA-1.

31 See id. at E-3, tbl. 3. 
Over the past several decades, the American economy has changed significantly. It has been transformed not only from an industrial to a white-collar, service, and retail economy, but also from long-term, stable employment relationships to short-term arrangements. ${ }^{32}$ Businesses do not hesitate to lay off large numbers of workers when necessary, and many firms use independent contractors and "permatemps" retained from external employment agencies. Millions of manufacturing and service jobs have been outsourced to low wage workers in countries like China, Malaysia, and India. ${ }^{33}$

As union density has declined, employee job security and economic circumstances have suffered. ${ }^{34}$ Few twenty-first century workers expect to be employed by the same firms throughout their adult lives. Over the past forty years, CEO compensation has risen dramatically, ${ }^{35}$ and the Dow Jones average has gone from under $\$ 1000$ to over $\$ 10,000$, despite the $2008-2009$ economic crisis. During this same period, the real wages and benefits of regular workers has been stagnant. Without a collective

32 See generally KATHERINE V.W. STONE, FROM WIDGETS TO DIGETS 67-86 (2004).

33 See generally THOMAS L. FRIEDMAN, THE WORLD IS FLAT (2005); ROBYN MEREDITH, THE ELEPHANT AND THE DRAGON (2007).

34 See generally STEVEN GREENHOUSE, THE BIG SQUEEZE (2008).

35 In 2005, the median compensation of the CEOs at 350 large publicly traded corporations was $\$ 6.8$ million. See DAILY LABOR REPORT (B.N.A.), April 11, 2006, at A-9. CEOs who used to earn about 40 times what blue-collar workers earned in 1960 now earn almost 500 times what typical employees earn. See Jennifer Reingold, Executive Pay, BUS. WK., April 17, 2000, at 110. 
voice provided by union representation, employees have not been able to share in the economic growth U.S. businesses have seen over the past twenty years. ${ }^{36}$

A study conducted by Professors Richard Freeman and Joel Rogers about ten years ago found that 87 percent of workers would like some form of collective voice to influence firm decisions that affect their job security and employment conditions - almost half would like traditional union representation, but fear employer reprisals if they openly support unionization. ${ }^{37}$ Many employers now recognize the minimal monetary remedies available under the NLRA for unfair labor practices. If they unlawfully terminate union supporters, they only have to provide those persons with back pay and reinstatement, and these remedies often take effect several years after the union organizing campaigns in question. Threats of adverse consequences if workers select exclusive bargaining agents do not result in any monetary remedies. The offending employers are simply directed not to engage in similar behavior in the future.

The NLRA has failed to keep up with economic developments over the past fifty years. ${ }^{38}$ The statute was designed primarily for expansive manufacturing companies that would have to accept the inevitability of unionization. The statute does not work well with respect to service and retail firms that are strongly opposed to unionization and will do almost anything to defeat organization campaigns. The labor movement has also failed

36 See generally CENTURY FUND, THE NEW AMERICAN ECONOMY: A RISING TIDE THAT LIFTS ONLY YACHTS (2004).

37 See RICHARD B. FREEMAN \& JOEL ROGERS, WHAT WORKERS WANT 147 (1999).

38 See generally Cynthia Estlund, The Ossification of American Labor Law, 102 COLUM. L. REV. 1527 (2002). 
to adapt to twenty-first century workers. Many continue to employ blue-collar organizing campaigns to appeal to new age white-collar and service personnel who think that conventional unions consist of "working class" and unprofessional members.

This article will consider changes that should be made in the NLRA if it is to be a meaningful factor in the coming years. How should the statute regulate the employment relationships of twenty-first century workers? What unfair labor practice remedies should be provided to deter and rectify improper conduct? How should the union certification procedures be changed to make it easier for workers who truly desire union representation to select bargaining agents? What should be done when newly certified labor organizations find it difficult to obtain initial bargaining agreements?

We will also contemplate ways in which union leaders must adapt to changing circumstances. The recent formation of the Change-to-Win Coalition is a step in the right direction, as leaders from unions like the Service Employees, the United Food and Commercial Workers, the Teamsters, the Laborers, and UNITE-HERE endeavor to develop new organizing tactics that may appeal to contemporary employees. We will finally explore ways in which individuals who would like a collective voice -- but not through conventional union representation -- could be provided with meaningful participation rights.

\section{HOW TO MAKE THE NLRA RELEVANT IN THE TWENTY-FIRST CENTURY}

Since the adoption of the NLRA, significant issues have arisen in three major areas. First, the scope of statutory coverage - what workers are entitled to NLRA protection? Second, the manner in which labor organizations can establish majority 
support and the right to act as employee bargaining representatives. Third, what should

be done when selected unions are unable to achieve initial bargaining agreements?

\section{A. Scope of Statutory Coverage}

Following the enactment of the NLRA, the Labor Board and the courts provided workers with expansive statutory coverage. Lower level supervisory were allowed to be included in bargaining units, ${ }^{39}$ and the "economic realities test" was established by the Supreme Court to extend coverage to newspaper sellers who would have constituted “independent contractors" under traditional legal doctrines.

Unless the common-law tests are to be imported and made exclusively controlling, without regard to the statute's purposes, it cannot be irrelevant that the particular workers in these cases are subject, as a matter of economic fact, to the evils the statute was designed to eradicate . . Interruption of commerce through strikes and unrest may stem as well from labor disputes between some who, for other purposes, are technically "independent contactors" and their employers as from disputes between persons who, for those purposes, are "employees" and their employers. Inequality of bargaining power in controversies over wages, hours and working conditions may as well characterize the status of the one group as of the other. The former, when acting alone, may be as "helpless in dealing with an employer," as "dependent . . . on his daily wage" and as "unable to leave the employ and to resist arbitrary and unfair treatment" as the latter. ${ }^{40}$

Employers were displeased with these expansive Supreme Court decisions, and in 1947, they induced Congress to amend the NLRA definition of "employee" to expressly exclude both "supervisors" and "independent contractors." ${ }^{41}$ Subsequent Supreme Court decisions have expansively applied these statutory exclusions. Professional persons like

39 See Packard Motor Car Co. v. NLRB, 330 U.S. 485 (1947).

${ }^{40}$ NLRB v. Hearst Publications, Inc., 322 U.S. 111, 127-28 (1944) (citations omitted).

41 Pub. L. No. 101, 61 Stat. 136 (1947), codified at 29 U.S.C. § 152(3) (2000). 
licensed practical nurses and registered nurses, who do not possess the managerial authority traditionally associated with true supervisory status but who in the ordinary course of their regular duties give relatively rote directives to their assistants, have been found to constitute excluded supervisory personnel. For example, in NLRB v. Health Care \& Retirement Corp. ${ }^{42}$ the Court rejected a Labor Board finding that "a nurse's direction of less-skilled employees, in the exercise of professional judgment incidental to the treatment of patients" was insufficient to render them "supervisors." Such individuals would constitute excluded supervisory personnel so long as they had to exercise independent judgment of more than a routine nature when they directed the work of lessskilled employees. In NLRB v. Kentucky River Community Care, Inc., ${ }^{43}$ the Court rejected another Labor Board effort to extend statutory coverage to registered nurses who used "ordinary professional or technical judgment" to direct the work of aides, as it held that such persons were still "supervisors" because of their exercise of "independent judgment" when they directed the work of those aides.

In the late 1970s, faculty members at Yeshiva University decided they needed a collective voice to influence their employment conditions. Although such academics do not constitute "supervisors," due to their lack of control over subordinates, the Supreme Court held that they could not unionize since they were "managerial" employees who "formulate and effectuate management policies by expressing and making operative the decisions of their employer." ${ }^{4}$

${ }^{42} 511$ U.S. 571 (1994).

${ }^{43} 532$ U.S. 706 (2001).

${ }^{44}$ NLRB v. Yeshiva University, 444 U.S. 672, 682 (1980). 
[T]he faculty of Yeshiva University exercise authority which in any other context unquestionably would be managerial. Their authority in academic matters is absolute. They decide what courses will be offered, when they will be scheduled, and to whom they will be taught. They debate and determine teaching methods, grading policies, and matriculation standards. They effectively decide which students will be admitted, retained, and graduated. On occasion, their views have determined the size of the student body, the tuition to be charged, and the location of a school. When one considers the function of a university, it is difficult to imagine decisions more managerial than these. ${ }^{45}$

The nursing and university professor decisions have made it difficult for professional individuals to obtain NLRA coverage, even where they do not possess the authority generally associated with true supervisory or managerial status. True supervisors have the power to hire, meaningfully direct, and discipline the work of subordinates. They do not merely give occasional professional directions to their assistants. Section 2(11) of the NLRA, ${ }^{46}$ should be amended to make it clear that the only persons excluded as "supervisors" include individuals who not only have the authority to meaningfully direct the work of others but also possess the power to discipline such coworkers if they fail to carry out their directives. Professionals who have the authority to hire, meaningfully direct, and discipline subordinates should certainly continue to be excluded. Nonetheless, professionals such as registered and licensed practical nurses who merely direct the basic work of aides without the power to hire or discipline such individuals should be considered "employees" who have the right to organize and to engage in collective bargaining under the statute.

45444 U.S. at 686.

${ }^{46} 29$ U.S.C. § 152(11) (2000). 
Congress should similarly amend Section $2(3)^{47}$ to limit the scope of the common law "managerial" exclusion. Only those individuals who meaningfully participate in the determination of important management policies affecting employment conditions should be excluded. Persons like professors who can affect academic policies but who have no meaningful influence over their own wages, hours, and working conditions should not be denied the right to select bargaining representatives.

As we have entered the twenty first century, employment relationships have changed significantly. The American economy has been transformed not only from an industrial to a white-collar and service economy, but also from long-term, stable employment relationships to shorter-term employment arrangements. ${ }^{48}$ Truck drivers who used to be employed by freight companies to drive trucks have been replaced by independent owner-operators who lease their vehicles to freight firms and are technically “independent contractors" excluded from NLRA coverage. Other employers have similarly replaced conventional employees with independent contractors who perform the same basic tasks under similar working conditions. Many companies bring in workers from employment agencies, like Man-Power Incorporated, to perform services on a long term basis. Such "parmatemps" are generally regarded as employees of the lending firms and not of the borrowing firms who really use their continued services.

Congress should amend the NLRA definition of "employee" to include the "economic realities" test articulated by the Supreme Court in the Hearts Publications

4729 U.S.C. $\S 152(3)(2000)$.

48 See generally KATHERINE V.W. STONE, FROM WIDGETS TO DIGITS 67-86 (2004). 
decision. ${ }^{49}$ Workers who are not truly independent contractors running their own separate businesses should be provided with statutory protection when they work primarily or exclusively for single employers and perform basic services for those firms under circumstances analogous to traditional master-servant relationships. Such a statutory modification would enable cab drivers, truck drivers, free-lance workers, and other persons who really function as "employees" of the corporations that retain their services to exercise the rights provided in the NLRA.

The Labor Board held in 2000 that an appropriate bargaining unit could include both regular employees and employees borrowed from temporary agencies on an ongoing basis. ${ }^{50}$ The user firm would be solely responsible for bargaining with the certified union with respect the wages and working conditions of regular employees and the user firm and the supplier agency would be jointly responsible for bargaining with respect to the "jointly employed" workers. In 2004, however, the Labor Board overruled M.B. Sturgis and held that such mixed bargaining units would only be permitted when both the staffing agency and the user firm consent to the inclusion of regular and temporary employees in the same unit. ${ }^{51}$ The Board should consider a return to M.B. Sturgis, and hold that where firms retain borrowed employees from temporary agencies on a regular basis for more than a minimal term - e.g., one or two years - a bargaining unit of the user firm could include both groups of employees. The user firm would be solely responsible

${ }^{49}$ See note 40, and accompanying text, supra.

${ }^{50}$ See M.B. Sturgis, Inc., 331 N.L.R.B. 1298 (2000).

${ }^{51}$ See H.S. Care L.L.C., 343 N.L.R.B. 659 (2004). 
for bargaining with respect to regular employees and jointly responsible with the lending agency for the terms of employment with respect to the borrowed employees.

As we have moved further into the twenty-first century, American firms have been employing an increasing number of undocumented aliens. Businesses may hire such individuals without knowledge of their unlawful status, but many either rely upon questionable forged documents or do not ask for appropriate documentation. Many of these employers do not provide such persons with the $\$ 7.25$ minimum wage, and they often fail to provide them with overtime pay for hours worked in excess of forty in a week. They know that such individuals would not dare to complain to Wage and Hour offices, due to their fear of deportation if their undocumented status is discovered. Employers are also comfortable knowing that they can terminate such workers if they have the temerity to support union organizing drives.

Sure-Tan, Inc. v. $N L R B^{52}$ concerned an employer that reported undocumented aliens to the Immigration and Naturalization Service in retaliation for their union activities. Although these individuals voluntarily agreed to leave the United States, the Supreme Court agreed with the Labor Board that such undocumented aliens constitute "employees" within the meaning of the NLRA, thus rendering the employer's retaliatory action an unfair labor practice under Section $8(a)(3) .{ }^{53}$ As a result of the unusual nature of undocumented aliens, the Supreme Court made the Board's reinstatement and backpay remedial order conditional on the discriminatees lawful reentry into the U.S. This

52467 U.S. 883 (1984).

53 See 29 U.S.C. § 158(a)(3) (2000) (prohibiting employer discrimination to encourage or discourage support for labor organizations). 
limitation was based upon the fact that employees must be considered unavailable for work and not entitled to backpay during any period when they are not lawfully entitled to be present and employed within the U.S. In Hoffman Plastic Compounds v. NLRB, ${ }^{54}$ a five-Justice Supreme Court majority expanded the remedial limitation it had imposed in Sur-Tan, as the Court held that the enactment of the Immigration Reform and Control Act $(\text { IRCA })^{55}$ in 1986, made it even clearer that the Labor Board may not order the reinstatement of, or award backpay to, undocumented workers illegally terminated by employers because of their otherwise protected activities - even if those remedies are conditioned upon the lawful reentry of the discriminatees into the U.S. "[A]llowing the Board to award backpay to illegal aliens would unduly trench upon explicit statutory prohibitions critical to federal immigration policy, as expressed in IRCA. It would encourage the successful evasion of apprehension by immigration authorities, condone prior violations of the immigration laws, and encourage future violations." ${ }^{, 56}$ The four dissenting Justices asserted that the denial of any backpay to undocumented workers especially those who had been knowingly or indifferently hired by employers - would reduce the cost to firms that illegally discharge employees for supporting labor organizations.

What the majority failed to appreciate in Hoffman Plastics was the fact it should have balanced the unlawful conduct by the employer - both in originally hiring the undocumented workers and in terminating their services and reporting them to the INS as

54535 U.S. 137 (2002).

55 Pub. L. No. 99-603 (1986), 8 U.S.C. § 1324 (2000).

56535 U.S. at 151. 
a result of their protected activities in support of a labor organization - against the unlawful entry of those individuals into the U.S. As the dissenting Justices acknowledged, when employers hire such persons either knowing of their illegal status or indifferent to that fact, those firms are violating IRCA with the intent to exploit the undocumented workers. When such employers decide to discharge those individuals because of their protected activities, the employers should not be permitted to escape remedial responsibility. On the other hand, it would clearly be inappropriate to grant such persons regular reinstatement due to the fact they are not lawfully present in the U.S.

Either Congress should consider an amendment to IRCA or the Supreme Court should contemplate a reassessment of its Hoffman Plastics decision to formulate an approach that would impose an appropriate cost to employers who violate the NLRA by illegally terminating employees while recognizing the unlawful status of undocumented workers. They could do this by allowing them to vote in any scheduled Labor Board election and be counted as part of the proposed bargaining unit, and granting them full backpay from the date of their illegal discharge until the case has been finally resolved and the employer has fully complied with other aspects of the Labor Board's remedial order. Although this approach would admittedly provide such persons with backpay covering time they could not lawfully have remained in the country, it is the only way to impose a meaningful remedy upon the party directly responsible for their current unemployment. The Labor Board should also be empowered to direct the reinstatement of such persons in the future, once they can demonstrate that they have lawfully reentered the U.S.

B. Means for Unions to Establish Majority Support 
When the NLRA was originally enacted, a number of labor organizations represented workers on a "members-only" basis. ${ }^{57}$ They negotiated agreements that only applied to individuals who were actual union members. Congress implicitly acknowledged these relationships in Section $7,{ }^{58}$ which granted employees the right "to bargain collectively through representatives of their own choosing," and Section $8(\mathrm{a})(5),{ }^{59}$ which made it an unfair labor practice for employers "to refuse to bargain collectively with the representatives of [their] employees, subject to the provisions of section 9(a)." Section 9(a) ${ }^{60}$ made it clear that "[r]epresentatives designated or selected for the purposes of collective bargaining by the majority of the employees in a unit appropriate for such purposes, shall be the exclusive representatives of all the employees in such unit for the purposes of collective bargaining ..." When Sections 7, 8(a)(5), and 9(a) are read together and in a manner consistent with the bargaining practices existing in 1935, it becomes clear that Congress intended to allow unions to continue to demand and receive bargaining rights on a members-only basis - except where a majority of employees had selected an exclusive bargaining agent that would bargain on behalf of all of the employees in the designated unit. ${ }^{61}$

In the original NLRA, Congress indicated that the Labor Board could certify an exclusive bargaining representative by way of "a secret ballot of employees, or ... any

57 See CHARLES J. MORRIS, THE BLUE EAGLE AT WORK 20-21 (2005).

5829 U.S.C. $\S 157$ (2000).

5929 U.S.C. $\S 158(a)(5)(2000)$.

6029 U.S.C. $\$ 159(a)(2000)$.

61 See generally MORRIS, supra note 57. 
other suitable method to ascertain" whether a particular labor union has the support of a majority of employees in a particular unit. ${ }^{62}$ Such Board certification could thus be based upon union membership cards, recognition strikes demanding employer recognition of a specific union, or secret ballot elections. In 1947, however, business firms trying to make it more difficult for unions to obtain Labor Board certification induced Congress to narrow the language in Section 9(c) to permit union certification only by way of secret ballot elections. $^{63}$

Although Professors Freeman and Medoff found that 87 percent of workers would like a collective voice today to influence their employment conditions, recognizing that individuals possess no meaningful bargaining power, most are hesitant to openly support union organizing efforts out of fear they will be terminated. ${ }^{64}$ The existing system makes it difficult for unions to organize employees where their employers are completely opposed to unionization. As soon as employers learn of incipient organizing campaigns, they begin to express their anti-union sentiments at "captive audience" speeches which employees must attend, through supervisory talks with individual employees, through postings on firm bulletin boards, e-mail communications, messages in pay check envelopes, and other similar channels. Pro-union employees may only engage in

62 See THEODORE J. ST. ANTOINE, CHARLES B. CRAVER \& MARION G. CRAIN, LABOR RELATIONS LAW: SELECTED FEDERAL STATUTES AND SAMPLE BARGAINING AGREEMENT 14 (2005).

63 See 29 U.S.C. $§ 159$ (c)(1) (2000).

64 See note 37, and accompanying text, supra. 
campaigning during non-work time,${ }^{65}$ and outside union organizers may almost never gain access to target employees on company premises. ${ }^{66}$

To provide union supporters with an equal opportunity to convey their pro-labor sentiments to fellow workers, Congress should amend the NLRA to require employers that express anti-union viewpoints to grant equal communication channels to employees who favor organization. If captive audience speeches are employed, pro-union workers should be given an equal amount of time to address the audience. If anti-union messages are posted on firm bulletin boards, sent through company e-mail systems, or placed in employee pay envelopes, union supporters should be allowed to express their views through the same mediums. Although employers clearly enjoy a First Amendment right to express their anti-union sentiments, ${ }^{67}$ they should not be allowed a wholly unbalanced privilege. If democratic elections are to be conducted, both sides should enjoy the same opportunities to convey their messages. Employers wishing to avoid the need to provide pro-union workers with such communication channels could easily do so by foregoing the use of communication means they do not wish to make available to union supporters. They could still convey their messages during non-work time, just as employees are allowed to do so. They could also send letters to employee homes, since pro-union workers could use this same medium.

\footnotetext{
${ }^{65}$ See Republic Aviation Corp. v. NLRB, 324 U.S. 793 (1945).

${ }^{66}$ See Lechmere, Inc. v. NLRB, 502 U.S. 527 (1992).

${ }^{67}$ See NLRB v. Virginia Electric \& Power Co., 314 U.S. 469 (1941). See also 29 U.S.C. $\S 8(c)$ (2000) (expressly protecting the free speech rights of employers and labor organizations under the NLRA).
} 
Even when unions are able to obtain authorization cards, indicating a desire for union representation, from a majority of employees in proposed units, employers may refuse to grant such organizations bargaining rights and force them to petition the Labor Board for representation elections. ${ }^{68}$ It can take fifty to sixty days from the time unions petition for elections until they are conducted. ${ }^{69}$ During this time, employers can repeatedly communicate with employees to indicate why they should not select bargaining agents. Although employers may not threaten or coerce employees, since such conduct would contravene Section $8(\mathrm{a})(1),{ }^{70}$ they have the express right to communicate their views regarding unionization so long as their statements to not contain threats of reprisal or promises of benefits. ${ }^{71}$ If they carefully formulate "predictions" that are based upon objective facts and express their opinion with respect to probable consequences arising from those facts, such communications are entirely permissible. ${ }^{72}$ They may thus be able to indicate that if unions are selected and generate increased labor costs, firms may be forced to close existing facilities. ${ }^{73}$

Some firms do not simply exercise their statutory right to communicate their antiunion perspective in a noncoercive manner. They employ anti-union consultants who

68 See Linden Lumber Division, Summer \& Co. v. NLRB, 419 U.S. 301 (1974).

69 See William B. Gould IV, The Employee Free Choice Act of 2009, Labor Law Reform, and What Can Be Done About the Broken System of Labor-Management Relations Law in the United States, 43 U.S.F. L. REV. 291, 315 (2008).

7029 U.S.C. $§ 158(a)(1)(2000)$.

71 See 29 U.S.C. $\$ 157$ (2000).

72 See NLRB v. Gissel Packing Co., 395 U..S. 575 (1969).

73 See, e.g., Crown Cork \& Seal Co. v. NLRB, 36 F.3d 1130 (D.C. Cir. 1994). 
frequently employ impermissible tactics. ${ }^{74}$ They overtly threaten proposed unit employees with lost employment if unions are selected. They have their clients discharge open union supporters, hoping to chill the pro-union activities of other workers. If they can terminate such persons in a humiliating fashion, they may be able to provoke an unprotected response that will end the right of the unlawfully fired persons to further backpay or reinstatement. ${ }^{75}$ Although the Labor Board believes that unlawfully terminated employees should refrain from unprotected actions and resort to administrative and judicial channels that may take several years to complete, this is both unfair and unrealistic. As soon as open union supporters are fired, remaining employees are afraid to openly express their support for union representation.

The inappropriate impact of unlawfully terminated union supporters is exacerbated if the discharged individuals lose their right to backpay and reinstatement because of unprotected responses. The appropriate approach was recognized by the D.C. Circuit Court of Appeals:

[W] here an employer who has committed unfair labor practices discharges employees for unprotected acts of misconduct, the Board must consider both the seriousness of the employer's unlawful acts and the seriousness of the employees' misconduct in determining whether reinstatement would effectuate the policies of the Act. Those policies inevitably come into conflict when both labor and management are at fault. To hold that employee "misconduct" automatically precludes compulsory reinstatement ignores two considerations which we think important. First, the employer's antecedent unfair labor practices may have been so blatant that they provoked employees to resort to unprotected action. Second, reinstatement is the only sanction which prevents an employer from benefiting from his unfair labor practices through discharges

74 See generally MARTIN JAY LEVITT, CONFESSIONS OF A UNION BUSTER (1993).

75 See Clear Pine Mouldings, Inc., 268 N.L.R.B. 1044 (1984), enforced, 765 F.2d 148 ( $9^{\text {th }}$ Cir. 1985), cert. denied, 474 U.S. 1105 (1986). 
which may weaken or destroy a union. ${ }^{76}$

Even when the Labor Board previously balanced the misconduct of unfair labor practice strikers against the seriousness of prior employer violations, the Board refused to reinstate individuals who were guilty of violence or the immediate threat of violence. ${ }^{77}$

One way to ameliorate the negative impact of illegal terminations would be to amend the remedial provisions of the NLRA to provide the adversely affected individuals with expeditious reinstatement. At the present time, it can take one or two years from the time employees are unlawfully discharged until they are finally reinstated. By then, union organizing campaigns are often defeated. Even if prior representation elections won by employers are overturned and new elections are held, the lingering negative impact of illegal threats and employee terminations tends to cause many employees to still vote against representation.

The current remedial provisions of the NLRA are biased in favor of employers. The principal reason for this imbalance concerns the fact that pro-employer Congresses added the most effective unfair labor practice remedies to the NLRA as part of the 1947 Taft-Hartley Act amendments and the 1959 Landrum-Griffith Act amendments. Most of the new remedial provisions pertained to violations committed by labor organizations, and not to those perpetrated by employers. Section $10(1)^{78}$ specifies that charges alleging

76 Local 833, UAW v. NLRB, 300 F.2d 699, $702-03$ (D.C. Cir.), cert. denied, 370 U.S. 911 (1962).

77 See Kayser-Roth Hosiery Co., 187 N.L.R.B. 562 (1970), modified, 447 F.2d 396 (6 ${ }^{\text {th }}$ Cir. 1971). See also Oneita Knitting Mills v. NLRB, 375 F.2d 385 (4 ${ }^{\text {th }}$ Cir. 1967).

7829 U.S.C. $§ 160(1)(2000)$. 
illegal union secondary action contravening Section $8(\mathrm{~b})(4),{ }^{79}$ proscribing secondary activity, Section $8(\mathrm{e}),{ }^{80}$ outlawing secondary "hot cargo" agreements, or Section $8(b)(7),{ }^{81}$ prohibiting different forms of organizational or recognitional picketing, must be handled on an expedited basis. Whenever an employer alleges a violation of one of these provisions and the preliminary Labor Board investigation indicates that the charge is meritorious, the Board is required to seek an immediate injunctive order in district court against the offending union conduct. This action protects the employer's interests while the subsequent unfair labor practice proceedings are conducted, with any union that disobeys such an injunctive order being subject to contempt sanctions. If the Board fails to seek a restraining order against such prohibited union activity, the adversely affected employer may petition a district court for a writ of mandate ordering the Board to do so. ${ }^{82}$ If the Labor Board ultimately finds that the challenged union action does violate these provisions, it must issue a cease and desist order prohibiting any future conduct of a similar nature. In addition, employers affected by secondary activity which contravenes Section 8(b)(4) may sue the offending labor organization in district court to recover monetary relief for the damages they have sustained. ${ }^{83}$

7929 U.S.C. $\$ 8(b)(4)(2000)$.

8029 U.S.C. $\S 158(\mathrm{e})(2000)$.

8129 U.S.C. $§ 158(b)(7)(2000)$.

82 See Terminal Freight Handling Co. v. Solien, 444 F.2d 699, 703-04 (8 ${ }^{\text {th }}$ Cir. 1971), cert. denied, 405 U.S. 996 (1972).

83 See 29 U.S.C. $\S 187$ (2000). 
Employers that commit unfair labor practices are not subject to such mandatory injunctive orders. If a charge alleging a violation of Section 8(a) by a firm is filed and the Labor Board decides to issue a complaint, the Board may seek a preliminary injunction against the offending behavior under Section 10(j). ${ }^{84}$ The Labor Board is not statutorily obliged to seek such preliminary relief, and if it fails to do so, the adversely affected employees or labor organization may not compel that agency to do so. The Board rarely seeks preliminary relief against employer unfair labor practices under Section 10(j).

Employers that openly violate the statutory rights of their employees under the NLRA are generally emboldened by the fact they consider the relatively minimal costs associated with unfair labor practice liability to be outweighed by the increased costs they associate with unionization and collective bargaining. These firms ignore the moral ramifications of their illegal conduct, and take advantage of the fact Labor Board remedies with respect to coercive threats and unlawful terminations are wholly inadequate. There is absolutely no monetary remedy provided for employer threats. The sole remedy is a final Board cease and desist order instructing the offending party to refrain from further violations. The only monetary remedy involves a Board order requiring employers that have illegally terminated union supporters to make those individuals whole for the compensation they have lost. Even this cost is ameliorated by the fact that unlawfully fired employees must seek interim employment to minimize their economic loss during the pendency of Board proceedings. ${ }^{85}$ The adversely affected individuals will also be ordered reinstated, but this part of the remedial order is not very

8429 U.S.C. $§ 160(j)(2000)$.

85 See Phelps Dodge Corp. v. NLRB, 313 U.S. 177, 197 (1941). 
effective. Only about 40 percent of discriminatees accept offers of reemployment, and, of those who do, about 80 percent leave their employers within two years. ${ }^{86}$

The proposed Employee Free Choice Act (EFCA) would help to deter the unlawful termination of union supporters by employers by mandating the award of treble backpay to adversely affected workers. The increased costs associated with such discharges might deter some firms from such actions in an effort to avoid enhanced backpay orders. Treble backpay awards would also help to compensate the dischargees for the emotional and economic stress associated with such terminations.

Employers that commit flagrant unfair labor practices during union organizing campaigns may find themselves encumbered by remedial bargaining orders directing them to recognize and bargain with the unions involved if those labor organizations can demonstrate that they obtained majority support despite the firm violations. ${ }^{87}$

Congress should amend Section 10(1) of the NLRA to include two employer unfair labor practices within the area covered by mandatory temporary restraining orders while the charges are being litigated before the Board. Whenever discriminatory discharge claims are filed under Section 8(a)(3) and the preliminary investigation indicates that the charges are meritorious, the Board should be required to seek preliminary injunctive orders reinstating the discriminatees. If such individuals could be returned to their former employment environments on an expedited basis, the lingering

${ }^{86}$ See Paul Weiler, Promises to Keep: Securing Workers' Rights to Self-Organization Under the NLRA, 96 HARV. L. REV. 1769, 1792 (1983).

${ }^{87}$ See Gourmet Foods, Inc., 270 N.L.R.B. 578 (1984). 
impact of their terminations would be minimal. They could continue their pro-union proselytizing and encourage their fellow workers to support them.

I have been told by union organizers and union attorneys that most labor organizations do not petition for Labor Board elections unless they have obtained authorization cards signed by fifty, sixty, or even seventy percent of employees in proposed bargaining units. Nonetheless, unions continue to prevail in about sixty to sixtyfive percent of Board elections. ${ }^{88}$ This is due primarily to the fact employers have such a communication advantage during the time it takes for the Labor Board to schedule representation elections.

Labor supporters in Congress have endeavored to eliminate this imbalance through provisions in the proposed Employee Free Choice Act (EFCA). EFCA provides for the majority status of organizing unions to be determined by the Labor Board based upon card-check certification. Union organizers and their unit supporters would solicit authorization cards from employees unequivocally indicating that those individuals would like to have formal representation by the designated labor organization. Once a majority of unit personnel have executed such cards, the union could petition the Labor Board for certification.

Employer groups strongly oppose this aspect of EFCA, contending that true industrial democracy can only be preserved through secret ballot elections. They suggest that employees may be coerced into signing authorization cards by threatening organizers or social pressures. They equate Labor Board representation elections with political

88 See Michelle Amber, 2008 Union Win Rate Rises to 66.8 Percent, as Number of NLRB Elections also Increases, DAILY LABOR REPORT (B.N.A.), May 5, 2009, B-2, tbl. 1. 
elections, failing to acknowledge the undue economic influence possessed by employers compared to federal, state, and local politicians. When people vote in political elections, they do not fear that the outcomes may directly affect their future job security. On the other hand, they recognize that their employers, which have unequivocally expressed their opposition to union representation, may lay off workers or completely close unionized facilities. It should thus be clear that Labor Board elections are not free from such undue considerations.

When I have spoken to EFCA opponents who extol the virtue of secret ballot elections, they become quite upset when I suggest that the salaries and bonuses paid to corporate executives should be determined by secret ballot elections conducted with shareholders. While they maintain that secret ballot elections should be required for employees contemplating the selection of exclusive bargaining agents, they do not think that shareholders should possess the right to vote in secret ballot elections on issues of corporate significance. Most of these persons appear to believe that unions have never been able to obtain Labor Board certification except through secret ballot elections. They fail to appreciate the fact that the original NLRA authorized the certification of labor unions based upon signed authorization cards, until the 1947 statutory amendments, without significant difficulties. ${ }^{89}$

Supporters of EFCA contend that the Labor Board election process is tainted by employer economic power which is frequently used to intimidate employees contemplating unionization. They suggest that reliance upon authorization cards would provide a fairer way to determine whether a majority of employees really desire union

89 See note 62, and accompanying text, supra. 
representation. Opponents assert that some workers would be induced to sign authorization cards based on overt union coercion or subtle forms of social pressure. Overt coercion would clearly contravene Section $8(\mathrm{~b})(1)(\mathrm{A})^{90}$ and render the improperly obtained cards invalid. While it is true that some workers may feel social pressure to sign authorization cards if many coworkers support union organizing campaigns, such social pressure is likely to be far less significant than the fear of job losses anti-union employers might express. As a result of their economic dependence on continued employment, employees tend to be far more influenced by coercive employer tactics than by improper behavior by union supporters.

Employer groups maintain that unions would be able to obtain authorization card signatures from employees before targeted employers would be able to explain the negative aspects of union representation. Employers clearly have the right to express their views in this regard, so long as their statements are not coercive, ${ }^{91}$ and employees in proposed bargaining units should have the right to hear the pros and cons of unionization before they decide what to do in this regard.

Most employers learn fairly early about incipient union organizing campaigns from their own employees who mention such endeavors to supervisory personnel. Nonetheless, labor organizations would still have several days to obtain signatures before employers could prepare their anti-union campaigns and express their sentiments to their employees. To offset this factor, Congress could include a provision in EFCA that would

\footnotetext{
9029 U.S.C. $\S 158(\mathrm{~b})(1)(\mathrm{A})$ (2000) (proscribing union interference with protected employee rights).

91 See note 67, and accompanying text, supra.
} 
require labor organizations seeking bargaining rights through authorization cards to notify targeted firms - and the appropriate Regional Offices of the Labor Board - of their planned campaigns. The statute could provide that only authorization cards signed after employers have received such notice would be considered when determining whether to extend bargaining rights to the unions involved. To avoid the improper forward-dating of cards signed by individuals before such employer notification, labor organizations could be required to obtain Labor Board imprints on the cards they plan to use when they initially notify employers and Labor Board offices of their anticipated campaigns. In exchange for their right to be notified of incipient union organizing drives, Congress might contemplate the recent proposal by Representative Joe Sestak (D. Pa.) that would require employers to provide unions with the same means of communication being used by employers to oppose organizing efforts. ${ }^{92}$

Employers opposed to card-check certifications maintain that since some employees may be induced to sign authorization cards due to overt coercion or more subtle social pressure, bargaining rights may be extended to labor organizations that do not really have majority support. To avoid such a result, Congress could modify the current EFCA bill to require a weighted majority before bargaining rights would be extended by the Labor Board. Unions could be required to sign up 60, 70, or even 75 percent of individuals in particular bargaining units before certification could be provided. Such an approach would greatly diminish the likelihood that exclusive

92 See Ryan Davis, Bill to Ease Union Organizing Reintroduced, http://employment.law360.com/articles/91030 (March 12, 2009). 
bargaining rights would be granted to unions that did not actually possess majority employee support.

Members of Congress who think that only secret ballot elections should be employed to grant certification to labor unions might consider a secret ballot alternative that would require the Labor Board to conduct elections within five or ten days after election petitions have been filed. This is the practice followed by several Canadian provinces. ${ }^{93}$ Such an approach would significantly shorten the fifty to sixty days most employers currently have to conduct their anti-union campaigns prior to Board elections. ${ }^{94}$ Both employers and labor organizations would have sufficient time to disseminate their pro- and anti-union messages, and the use of such expedited elections would decrease the ability of employers to improperly influence potential voters through express or implicit job loss statements.

When labor organizations have earned representation rights through Labor Board elections, employers often refuse to recognize the validity of the Board certifications. They file post certification objections challenging the validity of the elections and delaying the union certifications before Regional Directors and, in some cases, through appeals to the Board itself. After these representation procedures have been exhausted, the companies still refuse to recognize the certified unions, forcing the affected labor organizations to file refusal to bargain charges. During the resulting Board proceedings, the employers challenge the validity of the union certifications. Even though the Board does not permit such parties to relitigate the certification issues resolved in the prior

${ }^{93}$ See Gould, supra note 69, at 317.

94 See id. at 315. 
proceedings, administrative law judges must still conduct hearings to be sure the parties are subject to Board jurisdiction before they issue remedial bargaining orders. The ALJ decisions are then appealed to the Labor Board. Once the Board affirms the ALJ decisions, the employers appeal or refuse to comply forcing the Labor Board to seek court of appeals enforcement. This entire post-election process may take two or even three years, during which time the employees who selected representative unions have seen no benefits. ${ }^{95}$

One way to minimize the impact of such employer delays would be to amend Section 10(1) to require the Labor Board to seek preliminary injunctive orders requiring the offending employers to recognize and bargain with the affected labor organizations whenever the Board determines that the employer challenges to the certification process are clearly without merit. This would compel the firms to sit down quickly with the prevailing unions to negotiate. While this would not require them to achieve bargaining agreements, it would place them at significant risk if the district courts issuing the Section 10(1) injunctive orders determined that the firms were not bargaining in good faith.

When unions obtain Labor Board certifications and are prevented from bargaining for several years while employers exhaust all available appeal procedures, the employees who selected such representatives sustain meaningful and calculable monetary damages.

95 One way to shorten this extended process would be to make Labor Board certification orders "final" Board orders subject to immediate judicial review or enforcement. This would avoid the delay caused while ALJs and the Board consider refusal to bargain claims resulting from employer refusals to honor the certifications. Nonetheless, employers refusing to recognize the validity of Board certifications could still delay the bargaining process for a year or more while they appeal or force the Board to petition courts of appeal to resolve certification issues. 
If the firms had recognized the newly certified unions following their selection and bargained in good faith, there is a good chance the parties would have achieved collective contracts that would have enhanced the wages and fringe benefits enjoyed by unit personnel. In NLRB v. Tiidee Products, ${ }^{96}$ the court held that the Labor Board was empowered to make such individuals whole for their economic losses where the employer challenges to the election results were clearly without merit by determining what wages and benefits they would most likely have obtained had the employers bargained in good faith and award such relief to the affected employees. In Ex-Cell-O Corp.,${ }^{97}$ however, the Board rejected this approach and held that it lacked the statutory authority to award such monetary relief due to the fact there would be no way of determining (1) if the parties would have achieved a first contract and (2) what the economic terms would have been had they done so.

If Section 10(l) were amended to require preliminary district court bargaining orders while representation issues are being litigated by dissatisfied employers in unfair labor practice proceedings, the adversely affected employees would suffer minimal economic losses if their respective unions and employers were to immediately bargain in good faith over initial contracts. It would be inappropriate to punish employers seeking meaningful judicial review of Board certifications to impose somewhat speculative makewhole remedies. Nonetheless, Congress should consider amendments that would authorize the Board to award such relief for manifestly unjustified refusals to honor clearly valid Board certifications. How would administrative law judges determine what

96426 F.2d 1243 (D.C. Cir.), cert. denied, 400 U.S. 950 (1970).

97185 N.L.R.B. 107 (1970). 
delaying employers might have agreed to if they had bargained with newly certified unions in good faith? They could rely upon Bureau of Labor Statistics data indicating what unionized firms of a similar nature provide to their employees in this particular geographical area. Such remedies would be inherently speculative, since it would never be clear that the parties would ever have achieved first contracts. In addition, even Bureau of Labor Statistics data could not demonstrate exactly what the parties would have agreed upon had they bargained in good faith. An alternative would be for Congress to adopt procedures designed to assist newly certified labor organizations obtain their own initial contracts.

\section{Procedures to Help Newly Certified Unions Obtain Initial Contracts}

The proposed EFCA would endeavor to deal with situations in which newly certified labor organizations find it difficult to negotiate first contracts by mandating mediation assistance when negotiating parties are unable to achieve contracts within ninety days and first offer interest arbitration if they are still not able to reach agreement after thirty additional days. This is a controversial provision, because it is not clear when or if the parties would have ever obtained a first contract -- even if both sides had bargained in complete good faith. This is especially true with respect to weak unions dealing with employers in highly competitive fields where increased labor costs could significantly affect their ability to remain in operation. Whenever such labor organizations began to think that they could not achieve much success at the bargaining table, they would find it easy to delay the negotiation process until the time for binding contract arbitration arose. 
If first contract arbitration were to be statutorily mandated after 120 days, Congress should decide what standards should be employed by arbitrators. Should they be empowered to dictate any initial terms they think appropriate or should their discretion be circumscribed? Congress should instruct them to consider what similar firms in the relevant geographical areas are providing their employees with respect to wages, fringe benefits, and other working conditions. They would examine the health care, pension plans, union security provisions, management rights clauses, grievance-arbitration procedures, and similar terms provided by comparable companies. To further restrict arbitrator discretion, the neutral adjudicators should be required to choose between the final offers tendered by the employers and labor organizations involved based upon the reasonableness of the relevant proposals. This could be accomplished on a total package basis or on an issue-by-issue basis. I would recommend the issue-by-issue approach to enable arbitrators to select - issue by issue - the more reasonable of the proposals being advanced by labor and management. Such a final offer approach would encourage bargaining parties to make reasonable proposals to each other if they hope to prevail in any necessary arbitral proceedings. It would diminish the likelihood of binding arbitration, with the parties often being able to reach their own accords as they narrowed the distance remaining between their respective positions in preparation for possible arbitration.

The interest arbitration procedures included in the proposed EFCA would cover the first two years of labor and management relationships. If the parties worked together during this period, their relationship should mature, with each appreciating the needs and interests of the other. By the end of this initial period, it should be much easier for 
representative labor organizations to negotiate subsequent agreements without the need for further congressional assistance.

Members of Congress who do not feel comfortable with binding arbitration might consider non-binding arbitration. The neutral adjudicators would conduct hearings, determine the relevant facts, and make non-binding, but public, recommendations to the parties. The labor and management representatives would then be obliged to return to the bargaining table. The public arbitral findings and recommendations would put pressure on the negotiating parties to seek agreements in line with the arbitral suggestions.

\section{UNION APPEALS TO NEW AGE WORKERS}

I have previously suggested that the labor movement needs to revisit the mid1930s if it is to reorganize itself in a manner that will enable it to appeal to twenty-first century workers. ${ }^{98}$ When the $\mathrm{CIO}$ was formed and industrial unions began to organize manufacturing employees, labor leaders quickly learned how to appeal to blue-collar personnel. They designed campaigns that would encourage those persons to appreciate the fact that without collective voices they could not hope to meaningfully influence their employment terms. They successfully organized workers in steel, automobile, electrical, rubber, and other similar industries. It was these efforts that enabled unions to achieve a membership density of 35 percent by the mid-1950s. ${ }^{99}$ Since that time, the union membership rate has steadily declined to its current 7.6 percent.

${ }^{98}$ Charles B. Craver, The Labor Movement Needs a Twenty-First Century Committee for Industrial Organization, 23 HOFSTRA LAB. \& EMPL. L.J. 69 (2005).

99 See note 13, and accompanying text, supra. 
Many contemporary labor unions continue to use blue-collar organizing techniques to appeal to new age white-collar, service, and professional employees. It was a similar problem in the mid-1930s which induced the Committee for Industrial Organization to split away from the AFL and form new industrial unions. The AFL unions had been trying to use craft union appeals to homogeneous skilled trades workers to organize heterogeneous manufacturing employees. The CIO unions realized that they had to develop appeals that would entice skilled, semi-skilled, and unskilled personnel to join together to achieve common goals.

The formation of the Change to Win coalition should help to motivate union leaders to contemplate new organizing techniques. As was true in the late 1930s and early 1940s, inter union competition can be highly beneficial, as different unions work to organize new age workers. They must, however, appreciate the fact that twenty-first century workers do not wish to be considered "working class." They think of themselves as white-collar professionals, even when they have relatively modest service positions at firms like Wal-Mart. They fear that membership in traditional labor unions will suggest that they hold less prestigious positions.

If unions hope to appeal successfully to new age workers, they have to do two things effectively. First, they need to focus on larger firms like Wal-Mart. Coordinated efforts by AFL-CIO and Change to Win affiliates might be successful. Most Wal-Mart employees have modest compensation and limited fringe benefits. If unions like the Service Employees and the United Food and Commercial Employees were to work together to target Wal-Mart employees, they might begin to organize the almost 1 percent of work force participants who work for this extraordinarily successful corporation. 
To reach Wal-Mart employees, unions must utilize the Internet. Labor organizations must develop means to obtain the e-mail addresses of the targeted individuals to enable them to send different e-mail messages. ${ }^{100}$ They must also encourage targeted employees to communicate among themselves, whenever possible, through firm e-mail systems, and through external e-mail channels. Mass mailings, home visits, and telephone calls are unlikely to have the same impact. New age workers spend hours on the Internet, and almost no time reading regular mail or talking personally with strangers.

The second thing unions must do is significantly modify their organizing appeals. New age workers wish to preserve a professional status even if their educational backgrounds and actual employment circumstances do not warrant such status. These individuals are afraid of traditional labor unions, since they cannot understand how organizations that represent truck drivers, assembly line workers, and janitors could possibly understand and enhance the interests of professional personnel. They think that if they join such entities, they will lose their professional status and be viewed as "working class." I witnessed a perfect example of this phenomenon when the Service Employees Union was able to organize the adjunct faculty members at George Washington University. Several adjunct faculty members told me they could not imagine being in a union that represents janitors!

${ }^{100}$ See generally Martin H. Malin \& Henry H. Perritt, The National Labor Relations Act in Cyberspace: Union Organizing in Electronic Workplaces, 49 KAN. L. REV. 1 (2000). See also ARTHUR B. SHOSTAK, CYBER UNION: EMPOWERING LABOR THROUGH COMPUTER TECHNOLOGY (1999). 
Despite their desire to be viewed as white-collar professionals, most service sector employees appreciate the fact they lack individual bargaining power and would like a collective voice. They simply do not want to become associated with conventional unions. This was similar to the situation labor organizations faced thirty years ago when they sought to represent school teachers and nurses. The National Education Association finally decided to represent teachers, and the American Nurses Association decided to do the same for nurses. These entities emphasized their professional natures and the fact they were not "unions." As a result, teachers and nurses felt comfortable joining these associations and allowing them to be their bargaining agents. Even the AFL-CIO affiliate - the American Federation of Teachers - was careful not to include the term "union" in its title. I have had many teachers and nurses tell me personally how important it was to them to be represented by an "association" rather than a "union."

Existing AFL-CIO and Change to Win affiliates can successfully organize new age workers, if they modify their appeals to reach individuals who view themselves as white-collar professionals. Instead of emphasizing traditional wage and fringe benefit issues, which may still be important to these persons, they need to focus on ways in which they can enhance their professional credentials. They should talk about efforts to advance their employment skills to expand their portability in areas in which they are unlikely to work for specific firms for more than a few years before they move on. They must create new entities that are designed to reflect the hopes and aspirations of people employed in service, finance, insurance, health care, and technology fields. Just as the Committee for Industrial Organization created new industrial unions in the mid-1930s, 
twenty-first century unions must create new "professional associations" that will appeal to new age personnel.

An Association of White-Collar Service Employees could be formed to appeal to individuals employed by firms like Wal-Mart, Costco, Safeway, and Macy's. Even though wage and health care issues are of significant interest to these persons, such an Association would need to give them the impression that membership in and representation by such an entity could further their white-collar professional interests. It would seek to enhance their employment skills to make them more portable, and to make it easier for them to move into management. It might seek to move such persons from hourly wages to monthly salaries that would make them appear to be more like the managers who supervise their work.

An Association of Finance Professionals could be formed to organize employees who work for commercial banks, mortgage entities, and brokerage houses. An Association of Insurance Professionals could be created to appeal to the many persons who work in the insurance area. An Association of Health Care Professionals could be used to organize the many health care employees who might not fit within the jurisdiction of the Nurses Association. Individuals employed as nurses aides, patient attendants, and hospital record keepers could be enticed to join and feel no loss of status as a result. A similar Association of Intellectual Property and/or Technology Professionals could be established to appeal to persons employed by software and hardware firms.

As many of these employees have their employment terms and job security threatened by the outsourcing of their work to low cost firms in countries like India and China, they are likely to become more receptive to collectivization. These professional 
associations could tailor their appeals to their particular circumstances by emphasizing the need for employer-provided training courses designed to keep their skills current with the latest computer technologies. These associations could also address the need to limit the outsourcing of jobs to foreign workers and/or to provide retraining and relocation opportunities for persons displaced by such outsourcing decisions. Profit sharing and stock option plans could be negotiated to allow employees in these white-collar professional positions to share directly in the financial gains they help to generate.

The professional associations covering service, finance, insurance, health care, and technology workers could be semi-autonomous affiliates of existing unions like the Service Employees. Such an arrangement would provide these new entities with strong leadership, effective legal assistance, and a strong financial base. Their status as separate professional associations would be crucial, however, it they wish to appeal successfully to new age workers.

Organizers working for these new professional associations would have to think of new ways to appeal to targeted new age employees. They would have to forego bluecollar appeals that have been used to organize production personnel. They should emphasize the fact that most American businesses have created their own professional associations to further their economic interests. Groups such as the U.S. Chamber of Commerce and the National Association of Manufacturers ${ }^{101}$ represent expansive industries, while narrower entities represent the plastics, chemical, pharmaceutical, and similar industry groups. The American Bar Association furthers the interests of attorneys,

101 See BRUCE E. KAUFMAN, THE GLOBAL EVOLUTION OF INDUSTRIAL RELATIONS: EVENTS, IDEAS, AND THE IIRA 134-35, 221 (2004). 
while the American Medical Association serves a similar purpose for physicians. Rankand-file employees are the only major group in the U.S. without a collective voice. Union leaders of new professional associations must demonstrate to new age workers how powerless they are when acting individually. They must either accept the circumstances established unilaterally by their employers or seek other employment.

Professional association organizers must emphasize the fact that shareholders who combine their capital in corporate forms do not view collectivization as unprofessional or working class. These shareholders are quintessential capitalists who have combined their economic power to advance their personal wealth. This is why Congress noted in Section 1 of the NLRA the "inequality of bargaining power between employees who do not possess full freedom of association ... and employers who are organized in the corporate or other forms of ownership ..."102 Organizers need to convince new age workers that only through a collective voice can they hope to achieve employment terms that will reflect their true contributions to their respective firms.

Professional association officials must appreciate the fact that many new age workers do not wish to join or be represented by organizations that plan to foster conventional adversarial relationships with their employers. ${ }^{103}$ They would prefer more cooperative arrangements. In an increasingly competitive global economy, it is imperative that employee representatives cooperate with U.S. firms to maintain economically successful businesses. They need not do this, however, at the expense of the employees.

10229 U.S.C. $§ 151(2000)$.

103 See FREEMAN \& ROGERS, supra note 37, at 141-42. 
Over the past thirty years, shareholder wealth and managerial compensation have grown steadily, while employee wages and benefits have barely kept pace with inflation. ${ }^{104}$ Generous health care coverage has been diluted or eliminated, and beneficial defined benefit pension systems have been replaced by defined contribution 401(k) plans. It is imperative to recognize that the rights and benefits of individual employees have declined directly with the decline in union density rates. If unions were to completely disappear, individual workers would be powerless. Corporate employers would control their employment terms and continue to reduce the percentage of firm profits shared with regular workers.

If unions hope to survive and counterbalance the power possessed by increasingly larger business firms, they must convince employees of the need for a collective voice to advance their interests. If they continue to do this through traditional blue-collar appeals, they will fail and twenty-first century workers will suffer. On the other hand, if they can create new professional associations designed to appeal to new age white-collar professionals, they could reverse their decline and expand their overall base. If they could do this successfully, they could achieve union membership rates of 25, 30, or even 35 percent over the coming years. They could return to the hay days of the late 1940s and 1950s. They might even exceed the degree of union density which existed during those time frames.

\section{MANDATORY WORKER PARTICIPATION}

104 See generally GREENHOUSE, supra note 34. 
Even if the labor movement was able to create new professional associations that would appeal to new age workers and significantly increase the percentage of workers represented by bargaining agents, millions of employees would decide not to join such organizations. As a result they would lack any meaningful way to influence their basic employment terms. If such persons are to be provided with a significant voice, Congress would have to enact a new statute mandating some form of worker participation.

I have regularly heard corporate officials claim that their human capital is their most important firm resource. They often look for ways to make those persons more loyal and productive workers. Many have sought to accomplish this through shop level employee involvement programs. ${ }^{105}$ Such programs may be called "production teams" or “quality of work life programs." These mechanisms are designed to enhance communication between management and employees to improve the quality of the products or services being provided and to increase worker productivity. American business leaders appreciate the fact that firms in countries like Germany and Japan have used employee involvement committees to improve their positions in increasingly competitive global markets, and they hope to achieve similar benefits. ${ }^{106}$

Many of the worker participation programs already established by business firms technically violate Section 8(a)(2) of the NLRA, ${ }^{107}$ which makes it unlawful for an

105 See Samuel Estreicher, Employee Involvement and the "Company Union" Prohibition: The Case for Partial Repeal of Section 8(a)(2) of the NLRA, 69 N.Y.U. L. REV. 125, 137-38 (1994).

106 See Marleen A. O'Connor, The Human Capital Era: Reconceptualizing the Corporate Law to Facilitate Labor-Management Cooperation, 78 CORNELL L. REV. 899, 936-40 (1993).

10729 U.S.C. $\S 158(a)(2)(2000)$. 
employer to dominate "labor organizations." Section 2(5) of that Act ${ }^{108}$ expansively defines "labor organization" to include formal and informal employee committees that “deal with" employers with respect to "grievances, labor disputes, wages, rates of pay, hours of employment, or conditions of work." Even informal worker committees that act in a representative capacity on behalf of other workers and which deal with employers with respect to such matters constitute covered "labor organizations," and if employers exercise any meaningful control over their creation and/or operation, this contravenes Section $8(\mathrm{a})(2){ }^{109}$

To eliminate such Section 8(a)(2) difficulties, employers sought the enactment of the Teamwork for Employees and Managers Act (TEAM Act), ${ }^{110}$ which would have amended the NLRA to provide employers with greater freedom in this area. The TEAM Act was approved by the House and Senate, but was vetoed by President Clinton. ${ }^{111}$ President Clinton was not opposed to worker participation programs per se, but thought that the TEAM Act failed to protect employee interests. The proposed statute would have allowed employers to use such employee programs to enhance productivity and quality with minimal direct benefit to employees. Corporate managers would have been able to determine committee structures and agendas, without any concurrent obligation to allow workers to initiate discussions pertaining to more expansive issues.

10829 U.S.C. $\S 152(5)(2000)$.

109 See Electromation, Inc., 309 N.L.R.B. 990 (1992), enforced, 35 F.3d 1148 ( th $^{\text {th }}$ Cir. 1994).

110 H.R. 743, $104^{\text {th }}$ Cong. (1996); S. 295, $104^{\text {th }}$ Cong. (1996).

111 See DAILY LAB. REP. (B.N.A.) N0. 147, July 31, 1996, at AA-1. 
Business leaders frequently complain about the lack of employee commitment to firm objectives. What they fail to appreciate is the fact that as employees-at-will such individuals feel almost no firm loyalty toward them. They can be laid off or terminated at any time for almost any reason. The at-will doctrine and the absence of worker involvement in the managerial decision-making process makes employees feel insecure. ${ }^{112}$ Employees reasonably fear that recommended productivity enhancements will be rewarded - not by greater firm appreciation and monetary rewards - but by layoffs generated by the need for fewer workers. ${ }^{113}$ Employees also think that quality enhancements will be used to advance shareholder equities and managerial bonuses, but will not result in gain sharing for the workers involved. ${ }^{114}$

Corporate leaders who want to improve employee morale should recognize the potential benefits of meaningful worker participation programs. Through such institutions, employees could gain a greater appreciation for the competitive pressures challenging twenty-first century businesses, and firms could obtain valuable input from their knowledgeable workers. Federal legislation could authorize appropriately structured employee involvement committees to oversee firm compliance with safety and health regulations, wage and hour laws, civil rights statutes, and similar enactments.

112 See LESTER THUROW, HEAD TO HEAD 137-40 (1992).

113 See Aleta G. Estreicher, Beyond Agency Costs: Managing the Corporation for the Long Term, 45 RUTGERS L. REV. 513, 575-79 (1993) (discussing the impact of takeovers and restructuring on staff reductions).

114 See Marleen A. O'Connor, Restructuring the Corporation's Nexus of Contracts: Recognizing a Fiduciary Duty to Protect Displaced Workers, 69 U.N.C. L. REV. 1189, 1210 (1991) (discussing the "expropriation theory" which suggests that corporate restructuring generates corporate profits at the expense of employees). 
Cooperative employee involvement plans could also replace traditionally adversarial labor-management arrangements.

Congress must acknowledge that corporate success is dependent upon three symbiotic groups: (1) shareholders who provide the necessary capital; (2) managers who provide the required leadership; and (3) employees who generate the ultimate products or services. Shareholders are protected by federal and state securities laws that require corporations to provide shareholders with extensive information regarding firm operations, allow them to participate directly in the election of corporate directors, and which impose fiduciary duties on corporate managers. They also have the ability to diversify their stock holdings to ensure that no one firm can significantly affect their overall portfolios. Corporate managers are able to protect themselves from corporate vicissitudes through access to confidential firm information and their ability to make decisions that affect their own job security. Most have long term contracts that guarantee them employment for extended periods, and they usually have generous severance packages. They directly benefit from firm success through bonus payments and stock option plans that are unavailable to most rank-and-file employees. Regular workers enjoy almost no such benefits. They may commit their working lives to firm success, but normally receive almost no direct benefits for their efforts beyond their base salaries and their basic fringe benefits. They have no access to critical firm information, nor do they possess the opportunity to influence important corporate decisions that may affect their employment destinies. 
It is time for Congress to acknowledge that " $[\mathrm{t}]$ he essence of industrial democracy is the right of employees to influence decisions affecting their working lives."115 To accomplish this objective, Congress should enact an employer-employee relations act guaranteeing employees significant input with respect to business decisions that directly affect their employment situations.

Many European nations have established different types of employee involvement programs. ${ }^{116}$ Most of these plans have included shop level groups that focus on issues ranging from production and service methods to broader employment issues. These local bodies address topics of immediate interest to regular employees. A few worker participation programs provide for worker representation on corporate boards. This approach guarantees direct employee input when business firms are making fundamental corporate decisions that could directly affect employment concerns.

The U.S. prides itself in being a model democratic nation. Members of the general public have the ability to influence federal, state, and local executive and legislative activities through the direct election of mayors, governors, the President, city council members, state legislators, and members of Congress. On the other hand, in employment settings, America is one of the least democratic countries. Although employees are empowered to select exclusive bargaining agents to express their concerns, the vast

115 R. Willis, Minister for Employment and Industrial Relations, Employee Participation News No. 3, at 8 (1984), quoted in Lord Wedderburn, Trust, Corporation and the Worker, 23 OSGOODE HALL L.J. 203, 249 (1985).

116 See generally JOEL ROGERS \& WOLFGANG STREECK, eds., WORKS COUNCILS: CONSULTATION, REPRESENTATION, AND COOPERATION IN INDUSTRIAL RELATIONS (1995). 
majority of private sector employees no longer enjoy such representation even though almost 90 percent would like to have some type of collective voice.

Congress should create a legislative scheme that would provide regular employees and lower level managers with basic employment dignity and meaningful industrial democracy. Such a legislative program could only be effectively established by Congress. If individual states were to create such participation programs, they would risk the relocation of corporations to less intrusive jurisdictions. It would not be sufficient to simply enact something like the previously considered TEAM Act, because such a law would allow companies to establish employee committees designed to enhance product or service quality and worker productivity, with no reciprocal benefit to the employees themselves.

What incentives might be used to induce business firms to appreciate the benefits employers might derive from a mandatory worker participation law? Effective employee participation programs should advance productivity, quality, and worker morale. Employee turnover should decline, making it economically advantageous for firms to accept the costs associated with expanded firm-specific worker training. If employees were pleased with the input they would have through such legislated participation programs, they might decide not to view union representation as a necessary alternative. As the percentage of private sector workers in labor organizations has declined, diminishing the degree to which basic employment terms have been determined through the collective bargaining process, state legislatures, Congress, and judges have expanded the protections available to individual employees. As part of a mandated worker participation scheme, Congress could authorize local worker committees to oversee 
compliance with federal and state employment standards and to even grant waivers from some such regulations when warranted by appropriate local considerations.

Cooperative employee involvement programs could benefit both workers and their employers. Committees could ensure that firms consider the "human aspects" of corporate operations when they make decisions that could directly affect worker interests. This would provide employees with a feeling of respect and a satisfaction associated with their capacity to influence business decisions directly affecting their employment destinies. ${ }^{117}$ Such programs would also further employer-employee equality by correcting the present information and decision-making imbalance which allows managers to act opportunistically at the expense of information-deprived workers. ${ }^{118}$

Corporate officials need to appreciate the fact that rank-and-file employees frequently understand their functions more than the managers who supervise their work. Such employees are thus quite capable of developing plans that would enhance product or service quality and firm productivity. Why do they not strive to do so within existing corporate structures? They reasonably fear that such improvements would be likely to undermine their own job security. If businesses could be induced to treat their workers as partners in a cooperative venture and those individuals were allowed to share in company advancements, employees would be more inclined to suggest and support beneficial operational modifications.

117 See JAMES C. FURLONG, LABOR IN THE BOARDROOM: THE PEACEFUL REVOLUTION 91 (1977); A. H. Raskin, Toward a More Participative Work Force, in WORKING IN THE TWENTY FIRST CENTURY 90, 97 (C. Stewart Sheppard \& Donald C. Carroll, eds., 1980).

118 See O'Connor, supra note 114, at 1207-08. 
A mandatory worker participation program would not be a substitute for representative unions. Employee committees would not be authorized to negotiate over wages, hours, and working conditions, even though they could influence those topics. In addition, such committees would not possess the right to strike. Where labor organizations presently represent employees, those unions could work with employee participation committees to further worker interests. Where employees are currently not represented, effective employee committees might induce those workers to appreciate the more direct participation they could derive from the selection of formal bargaining agents. As a result, formal worker participation programs might help to expand - rather than contract - conventional union representation.

\section{A. Shop Level Employee Involvement Committees}

Congress should enact a statute that would require all employers with more than a minimum number of regular employees - perhaps twenty-five or fifty - to establish employee involvement committees. The law should require at least one committee for each separate facility with more than twenty-five employees. These committees could consist of at least five to ten employees, depending on the overall number of workers involved. Large facilities employing several hundred employees would be required to create subcommittees for each distinct department or group of interrelated departments whose workers share common employment interests. Multiple plant corporations should be obliged to create enterprise level employee involvement committees, comprised of individuals elected by the members of the different plant level involvement committees.

Every two or three years, employees would nominate and elect, by secret ballot procedures, the members of the different involvement committees. To enhance the 
interests of lower and middle management personnel who often find their employment interests more aligned with regular employees than with corporate managers, such persons should be authorized to elect one-quarter or one-fifth of committee members. Corporate leaders would also be permitted to appoint several involvement committee members to enable regular committee members to communicate directly with upper management representatives.

The statute should require firms to provide employee involvement committees with information pertaining to both basic operations and contemplated firm changes that could significantly affect working conditions and/or employee job security. The appropriate employee involvement committee or subcommittee would have the authority to consider proposed corporate changes that would affect basic operations or would involve the introduction of new technology, job restructuring, health and safety concerns, significant job or production relocations, group layoffs, and individual terminations. ${ }^{119}$ The full committees would consider issues of general concern, while subcommittees would focus on topics affecting their particular groups. Management officials would be obliged to consult with employee involvement committees before taking specific action in an effort to generate mutually acceptable outcomes.

In most instances, employee involvement committees and managers should be able to agree upon the appropriate courses of action. Committee members would appreciate the need for corporate efficiency and enhanced quality if firms are to remain competitive in the global economy. They should also acknowledge that redundant or

119 See PAUL C. WEILER, GOVERNING THE WORKPLACE: THE FUTURE OF LABOR AND EMPLOYMENT LAW 285-86 (1990). 
incompetent persons could not continue to be employed without threatening the job security of all employees. On the other hand, managers would have a better understanding of worker concerns and would obtain important input from the persons directly involved with the operations in question.

Congress could provide that when a weighted majority of employee involvement committee members oppose proposed managerial action, mediators with business experience could be brought in to assist the parties with their discussions. Time limits could be imposed to ensure that mediation efforts would not continue for prolonged periods. After business managers have consulted with committee members and participated in the decision-making process in good faith, they could be empowered to unilaterally implement proposals that have been rejected by committee members. This practice would be similar to that currently followed under the NLRA where bargaining parties are unable to achieve mutual accords and bargaining impasses are reached. ${ }^{120}$ Such an approach would not unduly restrict managerial freedom, but it would require firms to obtain input from and consult with employee involvement committees before they effectuated decisions of direct interest to workers.

Questions pertaining to the propriety of significant discipline imposed on employees could be subject to involvement committee review. In most cases, committee members would either accept the discipline imposed or induce management officials to modify or eliminate the penalties imposed. In the few cases in which no such agreements could be reached, Congress could require the matter to be sent to arbitration for final review. Traditional employment-at-will concepts should be replaced with more

120 See NLRB v. Katz, 369 U.S. 736 (1962). 
conventional "just cause" standards limiting the imposition of discipline to persons whose conduct is clearly inappropriate. To protect the right of businesses to discipline marginal or disruptive employees, Congress could reject the conventional American arbitral practice of requiring employers to demonstrate valid reasons for discipline imposed. ${ }^{121}$ It could instead require grieving employees to establish the absence of any reasonable basis for the discipline imposed.

Congress could help to reduce the expanding cost of judicial litigation by authorizing employee involvement committees to supervise the enforcement of safety and health regulations, wage and hour laws, family and medical leave provisions, civil rights laws, and similar employment statutes. Regular committee monitoring would be far more effective than the current system where understaffed federal and state agencies can only rarely visit covered facilities. Most employee challenges under these employment laws would be resolved amicably through discussions between committee members and management officials. In those rare instances in which mutual accords could not be achieved, Congress could provide for arbitral resolutions that would be subject to minimal judicial review.

\section{B. Board of Director Participation}

Shop level employee involvement committees could only provide workers with limited participation rights. Even though these institutions would significantly increase employee involvement with respect to daily decisions affecting their particular situations, they would not affect important decisions made by top corporate officials. If workers are

121 See ALAN MILES RUBEN, ed., HOW ARBITRATION WORKS 948-53 (6 $6^{\text {th }}$ ed. 2003). 
to be provided with the ability to meaningfully influence upper-management decisionmaking, legislation would have to provide them with board of director representation. ${ }^{122}$ Congress should acknowledge the significant contribution to firm success made by regular employees by mandating that one-fifth, one-quarter, or one-third of corporate board members be elected by non-executive personnel. Such a statute would provide both rank-and-file employees and lower-level managers with the right to nominate and elect worker representatives to corporate boards. This would guarantee that such boards consider worker interests when they debate and decide upon important firm policies. It would also encourage board members to look for ways to minimize the negative impact of decisions on employees.

Worker elected board members should not only serve the interest of employees. Both these board members and the shareholder elected directors should have a dual fiduciary obligation. All directors should be required to consider both shareholder and worker interests when they make business determinations, and they should be liable to employees or shareholders if they violate their fiduciary obligations to either group. ${ }^{123}$

Corporate boards have historically had a fiduciary obligation solely to advance the economic interests of shareholders. ${ }^{124}$ In more recent years, however, courts, legislators, and scholars have begun to question this single-minded fiduciary duty

122 See Michael H. Gottesman, In Despair, Starting Over: Imagining a Labor Law for Unorganized Workers, 69 CHI.-KENT L. REV. 59, 93-94 (1993).

${ }^{123}$ See id. at 93-95.

${ }^{124}$ See, e.g., Dodge v. Ford Motor Co., 170 N.W. 668, 684 (Mich. 1919). See generally Adolf A. Berle, Jr., For Whom Corporate Managers Are Trustees: A Note, 45 HARV. L. REV. 1365 (1932); ADOLPH A. BERLE \& GARDINER C. MEANS, THE MODERN CORPORATION AND PRIVATE PROPERTY 196-206 (1932). 
approach, suggesting that board members may consider groups other than just shareholders. ${ }^{125}$ One of groups most deserving of fiduciary protection include the employees who labor for their corporate employers. Unlike shareholders who can diversify their holdings, workers devote their lives to the firms that employ them. Poor corporate decisions can jeopardize both their job security and their pension funds that often contain a significant amount of employer firm stock. Their contribution to company success is as substantial as the contributions of shareholders. It would thus be entirely appropriate for Congress to impose upon corporate boards - and top firm managers - a fiduciary obligation that would protect the interests of both shareholders and workers. Although board members and top managers should have a dual fiduciary duty toward shareholders and employees, such firm leaders should have sufficient discretion to enable them to make good faith decisions when shareholder and employee interests conflict, without fear of personal liability. Congress could incorporate the "business judgment rule" to provide board members and managers with sufficient freedom to enable them to make controversial determinations. ${ }^{126}$ Liability would not be imposed on corporate officials who could demonstrate that they fairly considered the interests of adversely affected constituencies and acted in good faith when they made the decisions being challenged. Nonetheless, if it could be shown that they failed to consider worker

125 See, e.g., Unocal Corp. v. Mesa Petroleum Co., 493 A.2d 946 (Del. 1985); Paramount Communications, Inc. v. Time, Inc., 571 A.2d 1140 (Del. 1989); MINN. STAT. § 302A.251(5). See generally Lawrence E. Mitchell, A Theoretical and Practical Framework for Enforcing Corporate Constituency Statutes, 70 TEX. L. REV. 579 (1992).

${ }^{126}$ Regarding the "business judgment rule," see HARRY G. HENN \& JOHN R. ALEXANDER, LAWS OF CORPORATIONS AND OTHER BUSINESS ENTERPRISES $\S 242$ (3d ed. 1983). 
interests or acted to further selfish personal or shareholder interests at the expense of employees, liability should be imposed as it would if they had failed to properly consider the interests of shareholders.

The right of employees to elect corporate board members and the imposition of dual fiduciary duties on such boards and on top managers toward both shareholders and workers would not guarantee that employee interests would always prevail. Nor would it unduly limit the freedom corporate officials need to advance the economic interests of their institutions. It would merely guarantee that such parties would fairly consider worker interests when they make firm decisions that could significantly affect the future interests of employees.

\section{CONCLUSION}

When the NLRA was enacted in 1935 , only 13.2 percent of nonagricultural employees were union members, and most were craft workers in AFL unions. Soon after the NLRA went into effect, the CIO was formed and it created a group of industrial unions that organized the emerging production industries. By the mid-1950s, 35 percent of workers were union members. The AFL and CIO unions united, and ceased competing with one another to organize employees. The NLRA was significantly amended both in 1947 and 1959 to limit the persons covered by that Act and to restrict the economic weapons available to labor organizations.

By the late 1970s and early 1980s, labor costs at unionized firms had increased and employers began to look for ways to eliminate representative labor organizations. Unions also began to lose members as America was transformed from a manufacturing economy to a retail, service, and white-collar economy. Technological developments 
enabled firms to replace many workers with machines, and globalization caused companies to outsource millions of jobs to low wage countries like China and India. By 1990 , only 16.1 percent of workers were union members, and today only 12.3 percent of employees are union members - a mere 7.2 percent of private sector workers.

As union membership has declined, shareholder and managerial wealth has expanded while worker wealth has stagnated. Although a substantial percentage of private sector workers would like collective voices to advance their employment interests, most fear employer reprisals if they openly support unions. NLRA remedies are weak, enabling businesses to threaten or even discharge union supporters with minimal economic costs.

If the NLRA is to adapt to twenty-first century circumstances, the definition of "employee" must be expanded to include white-collar professionals who do not meaningfully direct the work of others, technically independent contractors who, as a matter of economic reality, are effectively "employees" of the firms for which they work, and permatemps from employment services who work for prolonged periods for single companies. Undocumented aliens who work for businesses until they are discharged when they decide to support union campaigns should be entitled to back pay until their unfair labor practice cases are concluded.

NLRA procedures should be modified to expedite the union selection process and make it easier for union supporters to counter anti-union arguments made by employers. When firms communicate their anti-union messages, union supporters should have an equal opportunity to reply. Union certifications should either be determined through authorization card checks or through secret ballot elections conducted on an expedited 
basis. Temporary restraining orders should be required to immediately reinstate employees terminated because of their support for unions.

When newly certified labor organizations are unable to achieve first contracts, binding arbitration on a final-offer basis could be used to determine the initial terms of employment for the unionized employees. If Congress does not feel comfortable with binding arbitration, it could use fact-finding with non-binding recommendations.

Unions have to develop new organizing approaches to appeal to twenty-first century workers who consider themselves to be white-collar professionals and who feel uncomfortable being members of conventional unions. It would be beneficial for AFLCIO and Change to Win affiliates to create new professional associations that would appeal to service, finance, insurance, health care, and technology personnel. These entities must also promise to advance their professional interests, and not simply their economic interests.

Even if unions are able to organize new age workers and expand their membership rolls, most private sector employees will continue to lack a collective voice. To extend industrial democracy to these individuals, Congress should enact legislation mandating employee involvement committees that would enable worker representatives to obtain information regarding company circumstances and to be consulted before managers make decisions that would significantly affect employee interests. Congress should also mandate the election of employee representatives to corporate boards, and impose a dual fiduciary obligation on all corporate board members and top company officials that would protect the interests of both shareholders and workers. The "business 
judgment rule" could be used to protect leaders who make difficult decisions in good faith reasonably considering the interests of both shareholders and employees. 